\title{
An overview on sexually transmitted infections in Iran
}

\author{
Roksana Janghorban $^{1}$, Fatemeh Azarkish ${ }^{2}$
}

\begin{abstract}
${ }^{1}$ Assistant Professor in Reproductive Health, Community Based Psychiatric Care Research Center, Department of Midwifery, School of Nursing and Midwifery, Shiraz University of Medical Sciences, Shiraz, Iran

${ }^{2}$ Assistant Professor in Reproductive Health, Iranshahr University of Medical Sciences, Iranshahr, Iran
\end{abstract}

Received: 15 January 2016

Accepted: 08 February 2016

\section{*Correspondence:}

Dr. Fatemeh Azarkish,

E-mail: azarkish2005@yahoo.com

Copyright: (C) the author(s), publisher and licensee Medip Academy. This is an open-access article distributed under the terms of the Creative Commons Attribution Non-Commercial License, which permits unrestricted non-commercial use, distribution, and reproduction in any medium, provided the original work is properly cited.

\begin{abstract}
Sexually transmitted infections (STIs) cause a large proportion of the global burden of ill-health, disability, and death. This paper reviews the status of STIs in Iran in the three groups of infections are caused by bacterial, viral, and parasitic pathogens and then focuses on human immunodeficiency virus (HIV) infection. This review was carried out in the period of 1977-2015 by searching in PubMed, Scopus, Embase, Web of sciences, Google scholar, the Iranian databases such as MagIran, IranMedex and SID using relevant English and Persian key words. Articles, reports, fact sheets, and official publications of World Health Organization (WHO), the United Nations Program on HIV and AIDS (UNAIDS), The United Nations Children's Fund (UNICEF), and the Ministry of Health and Medical Education (MOHME) of Iran were reviewed. Data on the prevalence of STIs in Iran is sparse with very limited generalizability to the general population. But studies show that these infections are concentrated in high risk sub-groups of the population. Iran has a low national HIV prevalence, but an increased prevalence among people who inject drugs, shifting the country from low prevalence to a concentrated prevalence. It seems that the more improvement of HIV/AIDS prevention, care and treatment programs in Iran need to more attention toward controlling HIV/AIDS through sexual health, proper linkage among HIV/AIDS, STIs, and SRH programs, reduction of stigma and discrimination toward people living with HIV/AIDS, and increase to access at risk populations.
\end{abstract}

Keywords: Sexually transmitted diseases, Acquired immunodeficiency syndrome, HIV

\section{INTRODUCTION}

Sexually transmitted infections (STIs) are infections that are passed on from one person to another through sexual contact. STIs cause a large proportion of the global burden of ill-health, disability, and death. ${ }^{1}$ It is estimated that more than 1 million people acquire one of the infections every day in 2013. ${ }^{2}$ In 2008, the total incidence of four curable STIs - Chlamydia trachomatis, Neisseria gonorrhoeae, Syphilis and Trichomonas vaginalis- for the Eastern Mediaterranean region was estimated to be 26.4 million by the World Health Organization (WHO). ${ }^{1}$ These infections are caused by over 30 bacterial, viral, and parasitic pathogens. ${ }^{2}$ At first, this paper presents the status of STIs in Iran in the three groups of infections and then focuses on human immunodeficiency virus (HIV) infection.

\section{REVIEW OF LITERATURE}

This review was carried out in the period of 1977-2015 by searching in PubMed, Scopus, Embase, Web of sciences, Google scholar using different combinations of following search terms including "STIs", "STDs", "Chlamydia trachomatis", "Neisseria gonorrhoeae", "Syphilis", "Trichomonas vaginalis", "HIV", "AIDS", "HPV", "HSV", "HBS", "Chancroid", "Iran", 
"prevalence", "incidence", "surveillance system", and "care".

Articles, reports, fact sheets, and official publications of WHO, the United nations program on HIV and AIDS (UNAIDS), The United nations children's fund (UNICEF), and the Ministry of health and medical education (MOHME) of Iran were reviewed. The Iranian databases such as MagIran, IranMedex and SID were also searched with relevant English and Persian key words.

\section{PART ONE}

\section{STIs status in Iran}

According to WHO/UNAIDS report in 2003, incidence of urethral discharge and genital ulcer were 1.96 (10.000) and 8.4 (10.000), respectively. ${ }^{3}$ The executive board of the United Nations Development Program and the United Nations Population Fund showed that there were 700,000 reported cases of STIs in 2003 in Iran. ${ }^{4}$ Data on the prevalence of STIs in Iran is sparse with very limited generalizability to the general population.

\section{Bacterial infections}

\section{Gonorrhea}

There is a limited data related to gonorrhea infection in Iran, but it seems that the overall prevalence of it in general population is low (Table 1). In most studies at low risk people without symptoms, the prevalence varies from 0 to $2.4 \% .^{5-12}$ But the prevalence rises in studies which have done in prostitutes and people with urethritis. $^{13-15}$ Results of Zirak-Zadah et al and Zargooshi's studies showed that rate of resistance to standard treatment in prostitutes and men who had sexual contact with sex workers rose from 1977 to $2002 .{ }^{13-14} \mathrm{It}$ may be due to ban prostitution officially in those years and low health coverage for them. It could be an alarming characteristic of gonorrhea infection in Iran, but further studies are needed to confirm it.

Table 1: Gonorrhea prevalence in different populations in Iran.

\begin{tabular}{|c|c|c|c|}
\hline Author/Ref & City & Studied population & Prevalence (\%) \\
\hline Zirak-Zadah $\mathrm{T}$ et al ${ }^{14}$ & Tehran & 921 female sex workers & 12.1 \\
\hline Zargooshi $\mathrm{J}^{13}$ & Kermanshah & 162 men with urethritis & 67.28 \\
\hline Dezfulimanesh $\mathrm{M}$ et $\mathrm{al}^{5}$ & Kermanshah & 500 pregnant and non pregnant women, $15-49$ y.o. & 0.4 \\
\hline 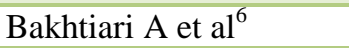 & Babol & 550 non-pregnant women, $15-45$ y.o. & 0.2 \\
\hline Rashidi B et al $^{7}$ & Tehran & $\begin{array}{l}209 \text { infertile women and } 170 \text { pregnant women in the } \\
\text { third trimester of pregnancy, } 18-40 \text { y.o. }\end{array}$ & Zero in both groups \\
\hline Shahcheraghi $\mathrm{F}$ et al ${ }^{16}$ & Tehran & $\begin{array}{l}500 \text { married female prisoners from Ewin, Rajaii } \\
\text { shahr, Karaj and Varamin prisons, 16-45 y.o. }\end{array}$ & $\begin{array}{l}48.6 \text { (by biochemical } \\
\text { tests) Zero (by PCR) }\end{array}$ \\
\hline Baghchesaraei $\mathrm{H}$ et $\mathrm{al}^{8}$ & Zanjan & $\begin{array}{l}328 \text { pregnant and non pregnant women referred to } \\
\text { gynecology and obstetrics clinics, } 15-45 \text { y.o. }\end{array}$ & 0.9 \\
\hline Akya A et al ${ }^{9}$ & Kermanshah & $\begin{array}{l}255 \text { married women referred to the gynecology } \\
\text { clinics, } 18-49 \text { y.o. }\end{array}$ & 2.4 \\
\hline Bahador $\mathrm{A}$ et $\mathrm{al}^{10}$ & Sabzevar & 399 pregnant adolescents women & 1.25 \\
\hline Ilami O et $\mathrm{al}^{15}$ & Yasuj & $\begin{array}{l}137 \text { patients ( } 28 \text { male \& } 109 \text { female) with } \\
\text { symptomatic urethritis }\end{array}$ & $\begin{array}{l}7.14 \text { (male) } \\
4.65 \text { (female) }\end{array}$ \\
\hline Hassanzadeh $\mathrm{P}$ et $\mathrm{al}^{11}$ & Shiraz & 1100 pregnant women & 1.18 \\
\hline Afrasiabi Sh et al ${ }^{12}$ & Kashan & $\begin{array}{l}294 \text { married women referred to the obstetrics and } \\
\text { gynecology clinics, } 17-55 \text { y.o. }\end{array}$ & 2.38 \\
\hline
\end{tabular}

\section{Chlamydia}

Chlamydia trachomatis is one of the most common STIs in the WHO Eastern Mediterranean region. ${ }^{1}$ The infection in Iran may not be as high as in developed countries, ${ }^{17}$ but studies in Table 2 show that its prevalence with 6.4$10.3 \%$ at low risk people without symptoms is more than gonorrhea. ${ }^{8,18}$ The rate increases in people (men and women) with urethritis, and women with cervicitis. ${ }^{19-24}$ Chlamydia trachomatis can lead to reproductive tract complications and pregnancy adverse outcome. ${ }^{25}$ This could be a remarkable issue in reproductive health and prenatal care in Iran because studies showed that the prevalence of Chlamydia trachomatis in pregnant women is higher than the low risk non-pregnant women. ${ }^{10,26}$ Additionally, the prevalence in infertile group and women with abortion is high. ${ }^{26-27}$

\section{Syphilis}

Syphilis prevalence in Iran is lower than $1 \%$ among pregnant women and other groups representative of the general population. ${ }^{37-39}$ In 2006, UNICEF reported that the prevalence in pregnant women was $85 / 100,000 .^{40}$ In 
Table 3, studies show that the infection is concentrated in a few high risk sub-groups of the population such as
HIV-positive patients, sex workers, and prisoners. ${ }^{41-44}$

Table 2: Chlamydia prevalence in different populations in Iran.

\begin{tabular}{|c|c|c|c|}
\hline Author/Ref & City & Studied population & Prevalence (\%) \\
\hline Darougar $\mathrm{S}$ et $\mathrm{al}^{28}$ & $\begin{array}{l}\text { Tehran \& Bandar } \\
\text { Abbas }\end{array}$ & 177 female sex workers & 6.9 \\
\hline Kajbaf M.J et al ${ }^{29}$ & Ahwaz & 101 infertile women & 7.9 \\
\hline Fallah $\mathrm{F}$ et $\mathrm{al}^{22}$ & Tehran & 122 women with cervicitis & 14.9 \\
\hline Naserpour Farivar $\mathrm{T}$ et $\mathrm{al}^{21}$ & Zahedan & 1054 patients with UTI symptoms & 9.02 \\
\hline Chamani-Tabriz L et al $^{18}$ & Tehran & 1052 women, $15-42$ y.o. & 6.4 \\
\hline Ghanaat $\mathrm{J}$ et $\mathrm{al}^{17}$ & Mashhad & 150 men with urethritis & 9.3 \\
\hline Rashidi B et $\mathrm{al}^{26}$ & Tehran & $\begin{array}{l}233 \text { infertile women and } 225 \text { pregnant } \\
\text { women }\end{array}$ & $\begin{array}{l}13.8 \text { (infertile group) } \\
11.1 \text { (pregnant group) }\end{array}$ \\
\hline Khezerdoust $\mathrm{S}$ et $\mathrm{al}^{30}$ & Tehran & $\begin{array}{l}1114 \text { pregnant women in } 11-32 \text { week of } \\
\text { gestation }\end{array}$ & 2.9 \\
\hline Sotoodeh Jahromi A et $\mathrm{al}^{27}$ & Bandar Abbas & $\begin{array}{l}200 \text { women with full-term deliveries \& } \\
220 \text { women with abortion }\end{array}$ & $\begin{array}{l}25.45 \text { (abortion group) } \\
5.20 \text { (full-term group) }\end{array}$ \\
\hline Taheri Beni B et $\mathrm{al}^{23}$ & Ahwaz & 620 women with cervicitis & 18.1 \\
\hline Asgari S et al2011 ${ }^{31}$ & Tehran & 130 prisoner men, $16-49$ y.o. & 2.3 \\
\hline Baghchesaraei $\mathrm{H}$ et al $^{8}$ & Zanjan & $\begin{array}{l}328 \text { pregnant and non pregnant women } \\
\text { referred to gynecology and obstetrics } \\
\text { clinics, } 15-45 \text { y.o. }\end{array}$ & 10.3 \\
\hline Hassanzadeh $\mathrm{P}$ et a ${ }^{32}$ & Shiraz & 210 pregnant women & Non-detection \\
\hline Eslami $\mathrm{G}$ et $\mathrm{al}^{33}$ & Tehran & 121 women with spontaneous abortion & 13.25 \\
\hline Ghazvini $\mathrm{K}$ et $\mathrm{al}^{19}$ & Mashhad & 178 men with urithritis & 10.6 \\
\hline Ilami $O$ et $\mathrm{al}^{15}$ & Yasuj & $\begin{array}{l}137 \text { patients ( } 28 \text { male } \& 109 \text { female) } \\
\text { with symptomatic urethritis }\end{array}$ & $\begin{array}{l}7.14 \text { (male) } \\
2.6 \text { (female) }\end{array}$ \\
\hline Afrakhteh $\mathrm{M}$ et $\mathrm{al}^{24}$ & Tehran & $\begin{array}{l}301 \text { women with STIs signs \& } \\
\text { symptomats }\end{array}$ & 24.91 \\
\hline Akya $\mathrm{A}$ et al ${ }^{9}$ & Kermanshah & $\begin{array}{l}255 \text { married women referred to the } \\
\text { gynecology clinics, } 18-49 \text { y.o. }\end{array}$ & 3.1 \\
\hline Bahador A et $\mathrm{al}^{10}$ & Sabzevar & 399 pregnant adolescents women & 12.28 \\
\hline Yeganeh $\mathrm{O}$ et $\mathrm{al}^{20}$ & Tehran & $\begin{array}{l}200 \text { men (100 symptomatic, } 100 \\
\text { asymptomatic) }\end{array}$ & $\begin{array}{l}20 \text { (symptomatic) } \\
4 \text { (asymptomatic) }\end{array}$ \\
\hline Fathollahzadeh B et al ${ }^{34}$ & Tehran & $\begin{array}{l}200 \text { men (symptomatic \& } \\
\text { asymptomatic) }\end{array}$ & $\begin{array}{l}11 \text { (symptomatic) } \\
6 \text { (asymptomatic) }\end{array}$ \\
\hline Kazerooni PA et $\mathrm{al}^{35}$ & Shiraz & 278 female sex workers & $9+2 \times$ \\
\hline Aslanimehr $\mathrm{M}$ et $\mathrm{al}^{36}$ & Qazvin & 240 married women & 8.3 \\
\hline
\end{tabular}

Table 3: Syphilis prevalence in different populations in Iran.

\begin{tabular}{|c|c|c|c|}
\hline Author/Ref & City & Studied population & Prevalence $(\%)$ \\
\hline Khamisipour GR et $\mathrm{al}^{44}$ & Bushehr & 635 high risk groups & 2.4 \\
\hline Ayatelahi $\mathrm{J}$ et al ${ }^{38}$ & Yazd & 1484 pregnant women & Zero \\
\hline Ghorbani Gh et $\mathrm{al}^{45}$ & Tehran & 1041 soldiers & 0.1 \\
\hline Nokhodian Z et al ${ }^{46}$ & Isfahan & 163 female prisoners & Zero \\
\hline Navadeh S et al ${ }^{42}$ & Kerman & 177 female sex workers & 7.2 \\
\hline Badie $\mathrm{B}$ et $\mathrm{al}^{41}$ & Tehran & 450 HIV-positive patients & 5.3 \\
\hline Motamedifar $\mathrm{M}$ et $\mathrm{al}^{47}$ & Shiraz & 1100 pregnant women, $15-42$ y.o. & 1.4 \\
\hline Mohammadali $\mathrm{F}$ et al $^{48}$ & Tehran & $2,026,628$ blood donors & $10.5 / 10^{5}$ \\
\hline Jedary Attary $\mathrm{S}$ et al ${ }^{39}$ & Tehran & 605 pregnant women & Zero \\
\hline Beheshti Sh et $\mathrm{al}^{43}$ & Shiraz & 129 male prisoners, $14-60$ у.о. & 6 \\
\hline
\end{tabular}




\section{Viral infections}

\section{Human papillomavirus (HPV)}

There is a lack of population-based studies to determine the prevalence of HPV in the general population in Iran (Table 4), but a systematic review on national data showed that the prevalence is $76 \%$ in cervical cancer patients and $7 \%$ in healthy women. ${ }^{49}$ According to a meta-analysis of type-specific HPV prevalence in Iranian women, the six most common types were HPV 16, 18, 6, 11, 31, and 33; among them HPV 16 was the most frequent type. ${ }^{50}$ This study showed that HPV vaccine could be a useful prevention strategy against cervical cancer in Iran.

Table 4: HPV prevalence in different populations in Iran.

\begin{tabular}{|c|c|c|c|}
\hline Author/Ref & City & $\begin{array}{l}\text { Studied } \\
\text { population }\end{array}$ & $\begin{array}{l}\text { Prevalence } \\
(\%)\end{array}$ \\
\hline $\begin{array}{l}\text { Alavian SM et } \\
\mathrm{al}^{57}\end{array}$ & $\begin{array}{l}7 \\
\text { provinces }\end{array}$ & $\begin{array}{l}\text { Systematic } \\
\text { review }\end{array}$ & 2.14 \\
\hline $\begin{array}{l}\text { Zamani S et } \\
\mathrm{al}^{64}\end{array}$ & Isfahan & 118 IDUs & 0.7 \\
\hline $\begin{array}{l}\text { SeyedAlinaghi } \\
\text { SA et } \mathrm{al}^{59}\end{array}$ & Tehran & $\begin{array}{l}499 \text { male } \\
\text { IDUs }\end{array}$ & 5.8 \\
\hline $\begin{array}{l}\text { Fathimoghaddam } \\
\text { et al }^{65}\end{array}$ & Mashhad & $\begin{array}{l}1652 \\
\text { General } \\
\text { population }\end{array}$ & 1.39 \\
\hline $\begin{array}{l}\text { Khosravani A } \\
\text { et al }\end{array}$ & $\begin{array}{l}\text { Kohgiloyeh } \\
\& \\
\text { Boyerahmad }\end{array}$ & $\begin{array}{l}209 \text { High } \\
\text { risk } \\
\text { population }\end{array}$ & 1.2 \\
\hline $\begin{array}{l}\text { Babamahmood } \\
\text { F et al }\end{array}$ & Mazandaran & $\begin{array}{l}188 \mathrm{HIV} \\
\text { positive } \\
\text { persons }\end{array}$ & 11.3 \\
\hline $\begin{array}{l}\text { Nejad ME et } \\
\mathrm{al}^{63}\end{array}$ & Tehran & $\begin{array}{l}213 \text { HIV } \\
\text { positive } \\
\text { persons }\end{array}$ & 11.3 \\
\hline $\begin{array}{l}\text { Ziaee M et } \\
\mathrm{al}^{67}\end{array}$ & $\begin{array}{l}\text { Southern } \\
\text { Khorasan }\end{array}$ & $\begin{array}{l}881 \\
\text { prisoners }\end{array}$ & 6.9 \\
\hline $\begin{array}{l}\text { Nokhodian Z } \\
\text { et al }^{61}\end{array}$ & Isfahan & $\begin{array}{l}970 \\
\text { prisoners } \\
\text { IDUs }\end{array}$ & 3.3 \\
\hline $\begin{array}{l}\text { Ramezani A } \\
\text { et al }\end{array}$ & Arak & $\begin{array}{l}100 \text { male } \\
\text { IDUs }\end{array}$ & 6 \\
\hline
\end{tabular}

\section{Hepatitis $B(H B V)$}

A systematic review in Iran revealed that prevalence of HBV infection is approximately $2.14 \%$ (1.3\% to $6.3 \%)$ across provinces. ${ }^{57}$ Therefore, according to regional classification of carrier rate of HBV infection throughout the world, Iran is likely located in the group with intermediate prevalence $(2-7 \%){ }^{58}$ The prevalence is higher among populations at high risk for infection, particularly injecting drug users (IDUs). ${ }^{59-61}$ Studies showed that the prevalence of HBV in HIV positive persons was frequent (Table 5). ${ }^{62-63}$

Table 5: HBV prevalence in different populations in Iran.

\begin{tabular}{|c|c|c|c|}
\hline Author/Ref & City & $\begin{array}{l}\text { Studied } \\
\text { population }\end{array}$ & $\begin{array}{l}\text { Prevalence } \\
(\%)\end{array}$ \\
\hline 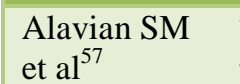 & $\begin{array}{l}7 \\
\text { provinces }\end{array}$ & $\begin{array}{l}\text { Systematic } \\
\text { review }\end{array}$ & 2.14 \\
\hline $\begin{array}{l}\text { Zamani S et } \\
\mathrm{al}^{64}\end{array}$ & Isfahan & 118 IDUs & 0.7 \\
\hline 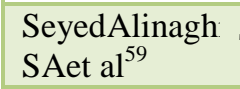 & Tehran & $\begin{array}{l}499 \text { male } \\
\text { IDUs }\end{array}$ & 5.8 \\
\hline $\begin{array}{l}\text { Fathimoghadda } \\
\mathrm{m} \mathrm{F} \text { et al }\end{array}$ & Mashhad & $\begin{array}{l}1652 \\
\text { General } \\
\text { population }\end{array}$ & 1.39 \\
\hline $\begin{array}{l}\text { Khosravani } \\
\text { A et al }\end{array}$ & $\begin{array}{l}\text { Kohgiloyeh } \\
\& \\
\text { Boyerahmad }\end{array}$ & $\begin{array}{l}209 \text { High } \\
\text { risk } \\
\text { population }\end{array}$ & 1.2 \\
\hline $\begin{array}{l}\text { Babamahmoo } \\
\text { d F et } \text { al }^{62}\end{array}$ & Mazandaran & $\begin{array}{l}188 \mathrm{HIV} \\
\text { positive } \\
\text { persons }\end{array}$ & 11.3 \\
\hline $\begin{array}{l}\text { Nejad ME et } \\
\mathrm{al}^{63}\end{array}$ & Tehran & $\begin{array}{l}213 \text { HIV } \\
\text { positive } \\
\text { persons }\end{array}$ & 11.3 \\
\hline $\begin{array}{l}\text { Ziaee } M \text { et } \\
\mathrm{al}^{67}\end{array}$ & $\begin{array}{l}\text { Southern } \\
\text { Khorasan }\end{array}$ & $\begin{array}{l}881 \\
\text { prisoners }\end{array}$ & 6.9 \\
\hline $\begin{array}{l}\text { Nokhodian } \\
\text { Z et al }{ }^{61}\end{array}$ & Isfahan & $\begin{array}{l}970 \\
\text { prisoners } \\
\text { IDUs }\end{array}$ & 3.3 \\
\hline $\begin{array}{l}\text { Ramezani A } \\
\text { et } \mathrm{al}^{60}\end{array}$ & Arak & $\begin{array}{l}100 \text { male } \\
\text { IDUs }\end{array}$ & 6 \\
\hline
\end{tabular}

\section{Herpes simplex virus (HSV)}

The prevalence of the HSV type 2 infections in North Africa and the Middle East was estimated 9.6 and 8.6 among females and males, respectively. ${ }^{68}$ In Iran, studies have shown that HSV-2 prevalence increases in high risk groups (Table 6). ${ }^{69-70}$ The typically asymptomatic nature of HSV-2, which facilitates its spread in the population, and its association with an increased risk of HIV acquisition highlight the increasing need to plan regular screening and safe sex programs in this group. ${ }^{68}$ Additionally, the high prevalence of the infection in pregnant women could be an important concern in prenatal care. ${ }^{71-72}$

\section{Parasitic infection}

\section{Trichomoniasis}

In a meta-analysis study in Iran, the overall prevalence rate of trichomoniasis was estimated $8 \% \quad(95 \%$ confidence interval $(\mathrm{CI})=0.07$ to 0.09$)$ with the maximum $38.8 \%(95 \% \mathrm{CI}=0.036$ to 0.042$)$ and the 
minimum $0.009 \%(95 \% \mathrm{CI}=0.008$ to 0.010$)$, respectively (Table 7). ${ }^{76}$ The prevalence of this infection increases in high risk behavior women such as prisoners. ${ }^{77}$

Table 6: HSV-2 prevalence in different populations in Iran.

\begin{tabular}{|c|c|c|c|}
\hline Author/Ref & City & $\begin{array}{l}\text { Studied } \\
\text { population }\end{array}$ & Prevalence (\%) \\
\hline 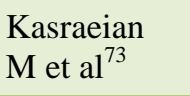 & Shiraz & $\begin{array}{l}915 \text { women, } \\
20-55 \text { y.o. }\end{array}$ & 28.19 \\
\hline $\begin{array}{l}\text { Ziyaeyan } \\
\text { M et al }^{72}\end{array}$ & Tehran & $\begin{array}{l}400 \text { pregnant } \\
\text { women }\end{array}$ & 8.25 \\
\hline $\begin{array}{l}\text { Shahraki } \\
\text { DA et } \mathrm{al}^{71}\end{array}$ & Isfahan & $\begin{array}{l}96 \text { pregnant } \\
\text { women }\end{array}$ & 34.75 \\
\hline $\begin{array}{l}\text { Asgari S et } \\
\mathrm{al}^{69}\end{array}$ & Tehran & $\begin{array}{l}362 \text { low risk } \\
\text { women, } \\
156 \\
\text { prisoners }\end{array}$ & $\begin{array}{l}2.5 \\
\text { (low risk group) } \\
26.3 \\
\text { (High risk group) }\end{array}$ \\
\hline $\begin{array}{l}\text { Rezaei- } \\
\text { Chaparpordi } \\
\mathrm{S} \text { et } \mathrm{al}^{74}\end{array}$ & Gilan & $\begin{array}{l}800 \text { low risk } \\
\text { people }\end{array}$ & 3.5 \\
\hline $\begin{array}{l}\text { Amirjannati } \\
\mathrm{N} \text { et } \mathrm{al}^{75}\end{array}$ & Tehran & $\begin{array}{l}217 \text { infertile } \\
\text { men }\end{array}$ & 12 \\
\hline $\begin{array}{l}\text { Aletaha } \\
\text { SM et } \mathrm{al}^{70}\end{array}$ & $\begin{array}{l}\text { Kerma } \\
\text { nshah }\end{array}$ & $\begin{array}{l}239 \text { women } \\
\text { with } \\
\text { cervicitis }\end{array}$ & 5.4 \\
\hline
\end{tabular}

Table 7: Trichomoniasis prevalence in different populations in Iran.

\begin{tabular}{|lll|l|}
\hline Author/Ref & City & $\begin{array}{l}\text { Studied } \\
\text { population }\end{array}$ & $\begin{array}{l}\text { Prevalence } \\
(\%)\end{array}$ \\
\hline Rabiee S et al $^{78}$ & Hamadan & $\begin{array}{l}683 \\
\text { women }\end{array}$ & 2.2 \\
\hline $\begin{array}{l}\text { Valadkhani Z et } \\
\text { al }^{77}\end{array}$ & Tehran & $\begin{array}{l}\text { 450 female } \\
\text { prisoners }\end{array}$ & 10.2 \\
\hline Tehrani FR et al $^{79}$ & Tehran & $\begin{array}{l}1100 \\
\text { pregnant } \\
\text { women }\end{array}$ & 38.9 \\
\hline $\begin{array}{l}\text { Nourian A et al } \\
\text { (10 }\end{array}$ & Zanjan & $\begin{array}{l}1000 \\
\text { pregnant } \\
\text { women }\end{array}$ & \\
\hline $\begin{array}{l}\text { Hezarjaribi HZ et } \\
\text { al }^{81}\end{array}$ & Sari & $\begin{array}{l}1832 \\
\text { women }\end{array}$ & 7.3 \\
\hline $\begin{array}{l}\text { Cheraghi M et } \\
\text { al }^{82}\end{array}$ & Khuzestan & $\begin{array}{l}1448 \text { non- } \\
\text { pregnant } \\
\text { women }\end{array}$ & 8 \\
\hline $\begin{array}{l}\text { Sehhatie-Shafaie } \\
\text { F et al }^{83}\end{array}$ & Tabriz & $\begin{array}{l}\text { 1000 non- } \\
\text { pregnant } \\
\text { women }\end{array}$ & 9.2 \\
\hline $\begin{array}{l}\text { Hezarjaribi HZ et } \\
\text { al }^{76}\end{array}$ & 30 cities & $\begin{array}{l}\text { meta- } \\
\text { analysis }\end{array}$ & 8 \\
\hline
\end{tabular}

STI/HIV strategies, prevention measures, care services in Iran with a review on challenges and barriers

In 2006, The WHO collaborating centre provided a technical assistant for the development of the second generation HIV surveillance in Iran. STIs surveillance system was a component of the strategic plan and "strengthening prevention of transmission of HIV through service providing centers" integrated to "care and treatment of STIs" and changed to "prevention, care and treatment of STIs" and "standard precaution". ${ }^{37,84}$ The STIs surveillance system had four main components including: syndromic reports, etiologic reports, monitoring drug resistance, and epidemiological studies and surveillance database. Syndromic and etiologic reports of STIs are done on monthly cumulative reports in Iran. ${ }^{85}$

The Ministry of health and medical education (MoHME) implements various measures for STIs prevention and control including HBV vaccination for hepatitis B prevention; prophylaxis program for occupational exposures to $\mathrm{HBV}, \mathrm{HCV}$, and HIV; syphilis and HIV screening tests in pregnant women with high risk behaviors; provision of medical prophylaxis and free formula milk for infants and children with HIV-positive mothers. ${ }^{86-87}$

"Triangular Clinics" is an effective model for HIV prevention, care, and support in IDUs which provide harm reduction interventions (needle syringe programs and methadone maintenance treatment), sexually transmitted infection services, and care/support for people living with HIV/AIDS. ${ }^{88}$ Additionally, establishment of behavioral disease counselling centers which provide services for HIV/AIDS prevention, STIs counselling and treatment, and harm reduction is another of care services in Iran. ${ }^{87}$

Despite all efforts, lack of proper integration between HIV and sexual and reproductive health (SRH) policies and programs is the main challenge of improving quality and access to HIV services in Iran. The provision of SRH services is included in HIV/ AIDS programs while HIV/AIDS control strategies are not implemented in SRH programs. ${ }^{87}$ Weakness in gender sensitive STIs/HIV/ AIDS prevention policies forms the other challenge. ${ }^{89}$

In terms of barriers, There is some difficulties to access people at risk for STIs and HIV (homosexuals, female sex workers, people who inject drugs, sexual minorities, homeless people, and youth) in health systems. ${ }^{87,89}$ In Iran, men who have sex with men (MSM) and sex workers are punished by law. Therefore, fear of revealing their sexual identity is a great obstacle for receiving education and care. ${ }^{87}$ Despite young people form over one quarter of the Iranian population, they are excluded from STIs and HIV education and services due to stigma, shame or the fear of being judged, and lack of adolescent- 
friendly services. Amongst this group, street children and young IDUs are further excluded and marginalized. ${ }^{87,90}$

\section{PART TWO}

\section{HIV status in Iran}

Iran has a low national HIV prevalence of 0.14 , but an increased prevalence among people who inject drugs, shifting the country from low prevalence to a concentrated prevalence. Besides, there is a rise in sexual transmission and new infections among women in recent years. The most important HIV transmission route in Iran is drug injection, followed by sexual contact. The transmission routes were reported from 20 March 2012 to 20 March 2013 include IDU, 45.5\%, sexual transmission $36.8 \%$, mother to child transmission $2.9 \%$, unknown transmission mode $14.8 \%$, and no new cases of transmission through blood transfusion. ${ }^{91}$

According to the UNAIDS report in 2014, the estimated number of people living with HIV in Iran was 74000 (51000 - 110000), although, based on the data of case registry system, 28663 people were infected with HIV until September $21^{\text {st }}, 2014 .^{91-92}$ Until this time, of total registered cases, $89.3 \%$ were men and $10.7 \%$ were women. $^{91}$ The latest estimate showed that HIV prevalence rate in adults aged 15-49 years was $0.1-0.2 \%$, and it remained constant from 2011 to 2014. The estimated number of women aged $\geq 15$, living with HIV, in Iran, was $93000(6400-14000)$ in 2014. ${ }^{92}$ AIDS progress report of Iran showed that the estimated new high risk cases of HIV in 2014 were 4043 in IDUs, 2022 in sex workers, and 789 in MSM. ${ }^{93}$ The United Nations General Assembly Special Session (UNGASS) country progress report in 2015 showed that $7.3 \%$ of the total people who needed antiretroviral therapy (ART) in Iran, received it. The people were comprised of 1516 females and 4069 males. $^{91}$

\section{HIV strategies in Iran}

In 2001 for the first time, MoHME developed a five year strategic plan for the years 2002-2006. This plan with 11 strategies focused on partnership of governmental and non-governmental sectors to control HIV and AIDS in Iran. A monitoring and evaluation plan was not considered in this program. For the years 2007-2009, the $2^{\text {nd }}$ strategic plan was arranged with 10 strategies and a program for monitoring and evaluation. From 2010 to 2014 , the $3^{\text {rd }}$ strategic plan was developed in 10 strategies with focus on prevention of sexual transmission of HIV. ${ }^{93}$ The $4^{\text {th }}$ strategic plan was developed for the years 2015 2019. Key populations in this plan are people who inject drugs, vulnerable women, and people living with HIV/AIDS, prisoners, working children with drug problems, HIV positive pregnant women, Amphetaminetype stimulants (ATS) users, and students with drug problems. Provision of services to working children and students with drug problems and HIV screening in the general population with focus on most at risk population are important intervention areas which not covered in previous strategic plans in Iran. ${ }^{94}$ Street children are one of the HIV high risk groups in Iran, without prevention program till now. A study in Tehran showed that HIV prevalence in the children was $4.6 \% .^{95}$ It is estimated that 6400 students with drug problems will be new target population in the $4^{\text {th }}$ strategic plan. ${ }^{94}$ Additionally, this plan has identified pregnant women as a priority group for halting the vertical transmission of HIV. ${ }^{91,94}$

During the implementation of aforementioned strategic plans, the establishment of voluntary counseling and testing (VCT) centers in most provinces and cities were very effective program in Iran. At this time, there are 160 VCT sites and 60 centers in prisons. ${ }^{91}$

\section{Challenges in HIV surveillance system in Iran}

One of the most important challenges in HIV surveillance system in Iran is the unequal access to services. The factors that contributed to it are including "stigma, discrimination, knowledge gaps on HIV and inadequate availability of free services". Besides, inconsistent adherence to care and treatment services in IDUs, finding appropriate locations for service delivery for vulnerable women, and "shortage of availability of adequate treatment services for psychoactive and Methamphetamine drugs" in Non-IDUs and lack of trained staff are additional challenges in this area. ${ }^{91,94}$

Due to the most important route of HIV transmission in Iran, HIV positive men are more than women. Therefore, services were planned to respond to this group. Despite a shift in transmission route of the infection to sexual mode and increase of the number of HIV positive women, this plan and traditional barriers including economic and social dependency, maternal responsibilities, and financial constraints limit women's access to HIV facilities in Iran. ${ }^{94}$

Difficulties in the access to most at risk populations are the other one of challenges in Iran. Although it has improved with establishment of drop in center (DIC) and services for vulnerable women, but there are some problems in access to the other at risk populations such as sex workers, MSM, working children with drug problem and ATS users. ${ }^{91,94}$

Weak coordination in national programs among HIV/AIDS, drug abuse, and STIs and insufficient participation of private sector and non-govermental organizations in HIV/AIDS prevention and care are infrastructural challenges of HIV surveillance system in Iran. $^{89,94,96}$

Coverage of condom use is a concern in HIV prevention programs in Iran. Although the use of condom in sexual relationships represents one of the preventive strategies in the transmission of HIV, studies have shown that nearly 
$50 \%$ of women and men aged 15-49 years with multiple sexual partners did not use condoms during their last sexual intercourse. The indicator was reported $15 \%$ and $57 \%$ in IDUs and female sex workers, respectively. ${ }^{97}$ Furthermore, the accessible evidence indicates protective behaviors based on condom use were low among at risk populations. $^{98}$ Additionally, "lack of perceived threat, absence of protective motivation, inadequate knowledge, perceived lack of control, negative attitudes towards condom, misperception, unsupportive environments, and cultural norms" have been identified as barriers to condom use among at risk women. ${ }^{99}$ The situation could be a trigger for planning a better targeted education of high risk groups.

Finally, in terms of HIV treatment, despite the increased number of individuals who receive ART, there is a discordance between the growth coverage of treatment and need for ART. Several experts believe that this problem has occurred due to software overestimation in need of ART. This is because the AIDS-related mortality patterns from 2005 to 2011 showed no change or decrease of less than $25 \%$, in the country. ${ }^{93,100}$

\section{CONCLUSION}

It seems that the more improvement of HIV/AIDS prevention, care and treatment programs in Iran need to more attention toward controlling HIV/AIDS through sexual health, proper linkage among HIV/AIDS, STIs, and SRH programs, reduction of stigma and discrimination toward people living with HIV/AIDS, and increase to access at risk populations.

\section{Funding: No funding sources}

Conflict of interest: None declared

Ethical approval: Not required

\section{REFERENCES}

1. World Health Organization. Global incidence and prevalence of selected curable sexually transmitted infections - 2008. 2012: Available from: http://apps.who.int/iris/bitstream/10665/75181/1/978 9241503839_eng.pdf?ua=1.

2. World Health Organization. Sexually transmitted infections (STIs). Fact sheet $\mathrm{N}^{\circ} 110$. 2013; Available from: http://www.who.int/ mediacentre/ factsheets/ fs $110 / \mathrm{en} /$.

3. United Nations Program on HIV and AIDS. Epidemiological fact sheets on HIV/AIDS and sexually transmitted infections, Iran.2004: Available from: http://data.unaids.org/publications/FactSheets01/iran_en.pdf.

4. Executive Board of the United Nations Development Program and of the United Nations Population Fund. Draft country programme document for the Islamic Republic of Iran.2004: Available from: http://web.lb.unfpa.org/exbrd/2004/annualsession/dp fpa-irn-4.pdf.
5. Dezfulimanesh M, Tehranian N. Endocervical gonorrhea in pregnant and non pregnant women and follow up of the infected cases in Kermanshah Iran 2004. Pakistan Journal of Medical Sciences. 2005;21(3):313-7.

6. Bakhtiari A, Firoozjahi A. The prevalence of gonococcal infection in non pregnant women. Iranian Journal of Public Health. 2007;36(2):64-7.

7. Rashidi BH, Tabriz LC, Haghollahi F, Jeddi-Tehrani M, Ramezanzadeh F, Foroushani AR, et al. Prevalence of Neisseria gonorrhea in Fertile and Infertile Women in Tehran. Journal of Reproduction \& Infertility. 2009;9(4).

8. Baghchesaraei H, Amini B, Hossaini M. Prevalence of infection with Nisseria Gonorrhoeae and Chlamydia Trachomatis in women visitors of gynecology and obstetrics clinics in Zanjan Province of Iran. African Journal of Microbiology Research. 2011;5(17):2447-50.

9. Akya A. The frequency of Chlamydia trachomatis and Neisseria gonorrhoeae infections among women in Kermanshah, Iran. Asian Biomed. 2013;7(5).

10. Bahador A, Mohammadzadeh M, Haghighi F. Prevalence of Chlamydia Trachomatis, Neisseria Gonorrhoeae and Ureaplasma Urealyticum in Pregnant Women of Sabzevar - Iran. Sex Transm Infect. 2013;89(Suppl 1):A1-A428.

11. Hassanzadeh P, Mardaneh J, Motamedifar M. Conventional Agar-Based Culture Method, and Nucleic Acid Amplification Test (NAAT) of the cppB Gene for Detection of Neisseria gonorrhea in Pregnant Women Endocervical Swab Specimens. Iranian Red Crescent Medical Journal. 2013;15(3):207.

12. Afrasiabi S, Moniri R, Samimi M, Mousavi SG. The frequency of Neisseria gonorrhoeae endocervical infection among female carrier and changing trends of antimicrobial susceptibility patterns in Kashan, Iran. Iranian journal of microbiology. 2014;6(3):194.

13. Zargooshi J. Characteristics of gonorrhoea in Kermanshah, Iran. Sexually transmitted infections. 2002;78(6):460-1.

14. Zirak-Zadah T, Delavarian H, Bahavar M, Majidi V, Yaminifar R, Masoumi P. Penicillin-resistant strains of Neisseria gonorrhoeae in Shahre-Now. Tropical doctor. 1977;7(2):57-8

15. Ilami O, Rahimian SH, Kargar M, Sisakht AJ, Saeedinejad SZ, Hadinia A. Detection of Neisseria Gonorrhoeae and Chlamydia Trachomatis in Patients with Symptomatic Urethritis Using Multiplex PCR, Gram Stain and Urine Culture. Journal of Mazandaran University of Medical Sciences (JMUMS). 2013;23(103).

16. Shahcheraghi F, Shafiei M, Valadkhani Z. Detection of Neisseria gonorrhoeae from vaginal swabs of Ewin, Rajaii shahr, Karaj and Varamin female prisoners by PCR and culture methods. Pakistan journal of biological sciences: PJBS. 2010;13(4):198-200. 
17. Ghanaat J, Afshari J, Ghazvini K, Malvandi M. Prevalence of genital chlamydia in Iranian males with urethritis attending clinics in Mashhad. 2008.

18. Chamani-Tabriz L, Tehrani MJ, Akhondi M, Mosavi-Jarrahi A, Zeraati H, Ghasemi J, et al. Chlamydia trachomatis prevalence in Iranian women attending obstetrics and gynaecology clinics. Pakistan journal of biological sciences: PJBS. 2007;10(24):4490-4.

19. Ghazvini K, Ahmadnia H, Ghanaat J. Frequency of Chlamydia trachomatis among male patients with urethritis in northeast of Iran detected by polymerase chain reaction. Saudi Journal of Kidney Diseases and Transplantation. 2012;23(2):316.

20. Yeganeh O, Jeddi-Tehrani M, Yaghmaie F, Kamali $\mathrm{K}$, Heidari-Vala $\mathrm{H}$, Zeraati $\mathrm{H}$, et al. A survey on the prevalence of Chlamydia trachomatis and Mycoplasma genitalium infections in symptomatic and asymptomatic men referring to urology clinic of Labbafinejad Hospital, Tehran, Iran. Iranian Red Crescent Medical Journal. 2013;15(4):340.

21. Farivar T-N. Prevalence of Chlamydia Trachomatis Within Culture Negative Urine Specimens in Southeast of Iran. J Med Sci. 2006;6(2):245-8.

22. Fallah F, Kazemi B, Goudarzi H, Badami N, Doostdar F, Ehteda A, et al. Detection of Chlamydia trachomatis from urine specimens by PCR in women with cervicitis. Iranian Journal of Public Health. 2005;34(2):20-6.

23. Beni BT, Motamedi H, Ardakani MR. Genotyping of the prevalent Chlamydia trachomatis strains involved in cervical infections in women in Ahvaz, Iran. Journal of medical microbiology. 2010;59(9):1023-8.

24. Afrakhteh M, Mahdavi A, Beyhaghi H, Moradi A, Gity S, Zafargandi S, et al. The prevalence of Chlamydia trachomatis in patients who remained symptomatic after completion of sexually transmitted infection treatment. Iranian journal of reproductive medicine. 2013;11(4):285.

25. Marrazzo JM. Chlamydia trachomatis infection among women reporting sexual activity with women screened in family planning clinics in the Pacific Northwest, 1997 to 2005. American journal of public health. 2011;101(7):1284.

26. Rashidi BH, Tabriz LC, Haghollahi F, Ramezanzadeh F, Shariat M, Foroushani AR, et al. Prevalence of Chlamydia trachomatis Infection in Fertile and Infertile Women; A Molecular and Serological Study. Journal of Reproduction \& Infertility. 2009;10(1).

27. Sotoodeh AJ, Reza MF, Farideh M. Chlamydia trachomatis in Women with Full-Term Deliveries and Women with Abortion. American Journal of Infectious Diseases. 2010; 6(3).

28. Darougar S, Aramesh B, Gibson J, Treharne J, Jones B. Chlamydial genital infection in prostitutes in Iran. The British journal of venereal diseases. 1983;59(1):53-5.

29. Kajbaf MJ, Gholamnezhad A. Prevalence of Chlamydia trachomatis Antigen and Antibody in
Infertile Women in Ahwaz. Iranian Biomedical Journal. 1998;2(1):45-8.

30. Khezerdoust S, Haghollahi F, Roostaie S, Badami N, Naghizadeh MM, Jafarabadi M. Chlamydia trachomatis Infection in Pregnant Women. Journal Reproduction \& Infertility. 2009;2:121-8.

31. Asgari S, Chamani-Tabriz L, Allami A, Asadi S, Zeraati H, Gachkar L, et al. Urogenital chlamydia trachomatis infection among prisoner men. Archives of Clinical Infectious Diseases. 2011;6(2):74-7.

32. Hassanzadeh P, Sharifi H, Bazargani A, Khashei R, Emami A, Motamedifar M. Non-detection of Chlamydia trachomatis infection by polymerase chain reaction in pregnant Iranian women. Microbiology Research. 2012;3(1):8.

33. Eslami G, Goudarzi H, Taheripanah R, Taheri S, Fallah F, Moazzami B, et al. Chlamydia trachomatis Detection by Nested-PCR Method on Females Referred to Medical Centers of Tehran, Iran. Archives of Clinical Infectious Diseases. 2012;7(4):124-7.

34. Fathollahzadeh B, Bahador A, Majnooni A, Kamalimanesh B, Moshkani S, Hasanabad MH. Screening of Chlamydia trachomatis Infection in Men, Is It Necessary in Iran? Jundishapur Journal of Microbiology. 2013;6(10).

35. Kazerooni PA, Motazedian N, Motamedifar M, Sayadi M, Sabet M, Lari MA, et al. The prevalence of human immunodeficiency virus and sexually transmitted infections among female sex workers in Shiraz, South of Iran: By respondent-driven sampling. International journal of STD \& AIDS. 2014;25(2):155-61.

36. Aslanimehr M, Ghazvini MS, Saadat S, Barikani A, Farivar TN. Frequency of Chlamydia trachomatis in Endocervical Samples of Women Referred to a Gynecology Hospital in Qazvin, Iran. Biotechnology and Health Sciences. 2015;2(1).

37. Ministry of Health and Medical Education CfdC, HIV/STI Office. Situation Analysis of Sexually Transmitted Infections In the Islamic Republic of Iran. 2008.

38. Ayatelahi J, Zare A. Antenatal screening for syphilis in Yazd. Iranian journal of infectious diseases and tropical medicine. 2006;11(32):45-8.

39. Jedary Attary S, Daneshjou K, Hantooshzadeh S. Screening of syphilis in pregnant women reffered to Valiasr Hospital, Emam Khomeini Hospital. Iran J Pediatr. 2009;24(2):S38.

40. The United Nations Children's Fund. HIV/AIDS in Iran. 2006; Available from: http://www.unicef.org/ iran/media_2016.html.

41. Badie BM, Yavari Z, Esmaeeli S, Paydary K, Emamzadeh-Fard S, Alinaghi SAS, et al. Prevalence survey of infection with Treponema pallidum among HIV-positive patients in Tehran. Asian Pacific journal of tropical biomedicine. 2013;3(4):334-6.

42. Navadeh S, Mirzazadeh A, Mousavi L, Haghdoost A, Fahimfar N, Sedaghat A. HIV, HSV2 and syphilis prevalence in female sex workers in Kerman, South- 
East Iran; using respondent-driven sampling. Iranian Journal of Public Health. 2012;41(12):60.

43. Beheshti S, Salehi L, Ziadlou S. Prevalence of Commonly Encountered Sexually Transmitted Infections Among Imprisoned Incarcerated Women. Women's Health Bulletin. 2014;1(3).

44. Khamisipour G, Tahmasebi R. Prevalence of HIV, $\mathrm{HBV}, \mathrm{HCV}$ and syphilis infection in high risk groups of Bushehr Province, 1999. Iranian South Medical Journal. 2000;3(1):53-9.

45. Ghorbani G, Mohamadi H, Esfahani A. Prevalence of syphilis and Chlamydia trachomitis in soldiers. Journal Mil Med. 2009;11(2):109-14.

46. Nokhodian Z, Yazdani MR, Yaran M, Shoaei P, Mirian M, Ataei B, et al. Prevalence and risk factors of HIV, syphilis, hepatitis $\mathrm{B}$ and $\mathrm{C}$ among female prisoners in Isfahan, Iran. Hepatitis monthly. 2012;12(7):442.

47. Motamedifar M, Hassanzadeh P, Taghinia MA, Hassazadeh Y. Detection of Syphilis by Serologic Tests in Pregnant Iranian Women, Shiraz, Iran. Galen Medical Journal. 2013;2(3):126-30.

48. Mohammadali F, Pourfathollah AA. Changes in Frequency of HBV, HCV, HIV and Syphilis Infections among Blood Donors in Tehran Province 2005-2011. Archives of Iranian medicine. 2014;17(9):613.

49. Khorasanizadeh F, Hassanloo J, Khaksar N, Taheri SM, Marzaban M, Rashidi BH, et al. Epidemiology of cervical cancer and human papilloma virus infection among Iranian women-Analyses of national data and systematic review of the literature. Gynecologic oncology. 2013;128(2):277-81.

50. Jalilvand S, Shoja Z, Nourijelyani K, Tohidi HR, Hamkar R. Meta-analysis of type-specific human papillomavirus prevalence in Iranian women with normal cytology, precancerous cervical lesions and invasive cervical cancer: Implications for screening and vaccination. Journal of medical virology. 2015;87(2):287-95.

51. Mirzendehdel S, Nadji SA, Tabarsi P, Baghaei P, Javanmard P, Sigarroodi A, et al. Prevalence of HPV and HIV among female drug addicts attending a drop-in center in Tehran, Iran. International Journal of Gynecology \& Obstetrics. 2010;108(3):254-5.

52. Zandi K, Nejad HA, Farshadpour F, Rastian Z. Prevalence of various Human Papillomavirus (HPV) genotypes among women who subjected to routine Pap smear test in Bushehr city (South west of Iran) 2008-2009. cancer. 2010;1:11-3.

53. Shahramian I, Heidari Z, Mahmoudzadeh-Sagheb H, Moradi A, Forghani F. Prevalence of HPV Infection and high risk HPV genotypes (16, 18), among monogamous and polygamous women, In Zabol, Iran. Iranian Journal of Public Health. 2011;40(3):113.

54. Ghasemian E, Monavari S, Irajian GR, Jalali NM, Roudsari RV, Yahyapour Y. Evaluation of human papillomavirus infections in prostatic disease: a cross-sectional study in Iran. Asian Pacific journal of cancer prevention: APJCP. 2012;14(5):3305-8.

55. Manzouri L, Salehi R, Shariatpanahi S. Prevalence of human papilloma virus among women with breast cancer since 2005-2009 in Isfahan. Advanced biomedical research. 2014;3.

56. Khodakarami N, Moradi A, Mirzaei H, Farah F, Yavari P, Akbari ME. Frequency of Human Papillumavirus among Women with High-Grade Squamous Intraepithelial Lesions and Invasive Cervical Cancer Attending Shahid Beheshti University of Medical Sciences Clinics, Tehran, Iran. Iranian Journal of Public Health. 2014;43(11):1563-8.

57. Alavian SM, Hajarizadeh B, Ahmadzad-Asl M, Kabir A, Bagheri-Lankarani K. Hepatitis B Virus infection in Iran: A systematic review. Hepat Mon. 2008;8(4):281-94.

58. Alter MJ. Epidemiology of hepatitis B in Europe and worldwide. Journal of hepatology. 2003;39:64-9.

59. SeyedAlinaghi SA, Kheirandish P, Karami N, Salem S, Shirzad H, Jahani MR, et al. High prevalence of chronic hepatitis $\mathrm{B}$ infection among injection drug users in Iran: the need to increase vaccination of adults at risk. Acta Medica Iranica. 2010;48(1):5860.

60. Ramezani A, Amirmoezi R, Volk JE, Aghakhani A, Zarinfar N, McFarland $\mathrm{W}$, et al. HCV, HBV, and HIV seroprevalence, coinfections, and related behaviors among male injection drug users in Arak, Iran. AIDS care. 2014;26(9):1122-6.

61. Nokhodian Z, Yaran M, Adibi P, Kassaian N, Meshkati M, Ataei B. Seroprevalence of hepatitis B markers among incarcerated intravenous drug users. Journal of research in medical sciences: the official journal of Isfahan University of Medical Sciences. 2014;19(Suppl 1):S13.

62. Babamahmoodi F, Heidari GM, Mahdi NM, Delavarian L. The prevalence rate of hepatitis B and hepatitis $\mathrm{C}$ co-infection in HIV positive patients in Mazandaran province, Iran. Medicinski glasnik: official publication of the Medical Association of Zenica-Doboj Canton, Bosnia and Herzegovina. 2012;9(2):299-303.

63. Nejad ME, Ehsani SR, Rabirad N, Deljo R, Ranjbarn $\mathrm{S}$, Rezaee S, et al. Prevalence of $\mathrm{HBV}$ in HIV Patients Referred to Imam Khomeini Hospital, Tehran, Iran from 2008-2010. Iranian Red Crescent Medical Journal. 2013;15(4):379-80.

64. Zamani S, Radfar R, Nematollahi P, Fadaie R, Meshkati M, Mortazavi S, et al. Prevalence of $\mathrm{HIV} / \mathrm{HCV} / \mathrm{HBV}$ infections and drug-related risk behaviours amongst IDUs recruited through peerdriven sampling in Iran. International Journal of Drug Policy. 2010;21(6):493-500.

65. Fathimoghaddam F, Hedayati-Moghaddam MR, Bidkhori HR, Ahmadi S, Sima HR. The prevalence of hepatitis B antigen-positivity in the general population of Mashhad, Iran. Hepatitis monthly. 2011;11(5):346. 
66. Khosravani A, Sarkari B, Negahban H, Sharifi A, Toori MA, Eilami O. Hepatitis B Infection among high risk population: a seroepidemiological survey in Southwest of Iran. BMC infectious diseases. 2012;12(1):378.

67. Ziaee M, Sharifzadeh G, Namaee MH, Fereidouni M. Prevalence of HIV and Hepatitis B, C, D Infections and Their Associated Risk Factors among Prisoners in Southern Khorasan Province, Iran. Iranian Journal of Public Health. 2014;43(2):229-34.

68. Looker KJ, Garnett GP, Schmid GP. An estimate of the global prevalence and incidence of herpes simplex virus type 2 infection. Bulletin of the World Health Organization. 2008;86(10):805-12A.

69. Asgari S, Chamani-Tabriz L, Asadi S, Fatemi F, Zeraati $\mathrm{H}$, Akhondi $\mathrm{M}$, et al. HSV-2 seroepidemiology and risk factors among Iranian women: a time to new thinking. Iranian Red Crescent Medical Journal. 2011;13(11):818.

70. Aletaha S, Akya A, Salimi A, Ahmadi K. The Frequency of Herpes Simplex Type 2 Infection in Women with Cervicitis in Kermanshah city in 2011. Journal of Zanjan University of Medical Sciences \& Health Services. 2014;22(92):108-15.

71. Shahraki DA, Moghim S, Akbari P. Evaluation of the Serum Level of Herpes Simplex Type 2 Antibody among Pregnant Women in Shahid Beheshti Hospital, Isfahan. Journal of Research in Medical Sciences. 2010;15(4):243

72. Ziyaeyan M, Japoni A, Roostaee MH, Salehi S, Soleimanjahi H. A serological survey of Herpes Simplex Virus type 1 and 2 immunity in pregnant women at labor stage in Tehran, Iran. Pakistan journal of biological sciences: PJBS. 2007;10(1):148-51.

73. Kasraeian M, Movaseghii M, Fotouhi Ghiam A. Seroepidemiological study of herpes simplex virus type 2 (HSV-2) antibody in Shiraz, Iran. IJI. 2004;1(3):189-93.

74. Rezaei-Chaparpordi S, Assmar M, Amirmozafari N, Modiri L, Massiha A, Shokri-Fashtali S, et al. Seroepidemiology of herpes simplex virus type 1 and 2 in northern iran. Iranian Journal of Public Health. 2012;41(8):75.

75. Amirjannati N, Yaghmaei F, Akhondi MM, Nasiri M, Heidari-Vala H, Sehhat Z. Molecular and serologic diagnostic approaches; the prevalence of herpes simplex in idiopathic men infertile. Iranian journal of reproductive medicine. 2014;12(5):327.

76. Hezarjaribi HZ, Fakhar M, Shokri A, Teshnizi SH, Sadough A, Taghavi M. Trichomonas vaginalis infection among Iranian general population of women: a systematic review and meta-analysis. Parasitology research. 2015;114(4):1291-300.

77. Valadkhani Z, Assmar M, Hassan N, Aghighi Z, Amirkhani A, Kazemi F, et al. The prevalence of trichomoniasis in high-risk behavior women attending the clinics of tehran province penitentiaries. Iranian Journal of Medical Sciences. 2015;35(3):190-4.
78. Rabiee S, Fallah M, Zahabi F. Frequency of Trichomoniasis in Patients Admitted To Outpatient Clinics in Hamadan (2007) and Relationship between Clinical Diag-nosis and Laboratory Findings. Journal of research in health sciences. 2010;10(1):31-5.

79. Tehrani FR, Farahmand M, Abedini M, Hashemi Z. Prevalence of vaginitis in Iranian women-symptoms and clinical association. Medical Sciences Journal of Islamic Azad University Tehran Medical Branch. 2012;22(1):62-8.

80. Nourian A, Shabani N, Fazaeli A, Mousavinasab SN. Prevalence of Trichomonas vaginalis in Pregnant Women in Zanjan, Northwest of Iran. Jundishapur Journal of Microbiology. 2013;6(8).

81. Hezarjaribi HZ, Dalimi A, Ghasemi M, Ghafari R, Esmaeili S, Armat S, et al. Prevalence of Common Sexually Transmitted Diseases among Women Referring for Pap Smear in Sari, Iran.

82. Cheraghi M, Rahimi Z, Parsa S. Prevalence of Cervical-Vaginal Infections in the Pap-Smear Samples in Iran. Global journal of health science. 2013;6(1):p201.

83. Sehhatie-Shafaie F, Namazi A. Prevalence, Risk Factors, and Clinical Findings of Candidiasis and Trichomoniasis in Women Supported by Selected Health Centers of Tabriz, Iran. Crescent Journal of Medical and Biological Sciences. 2014;1(4):130-5.

84. WHO Collaborating Centre for HIV surveillence. Technical assistance. 2015; Available from: http://www.whohub-zagreb.org/technical-assistance.

85. Ministry of Health and Medical Education CfdC, HIV/STI Office. Guideline of STIs surviellance system in Iran. 2006.

86. Lankarani KB, Alavian SM, Peymani P. Health in the Islamic Republic of Iran, challenges and progresses. Medical journal of the Islamic Republic of Iran. 2013;27(1):42.

87. Moradi G, Khoshravesh S, Hosseiny M. Situation of linkage between sexual and reproductive health and HIV-related policies in Islamic Republic of Iran-a rapid assessment in 2011-2. International journal of health policy and management. 2015;4(3):131.

88. Razzaghi E, Nassirimanesh B, Afshar P, Ohiri K, Claeson M, Power R. HIV/AIDS harm reduction in Iran. The Lancet. 2006;368(9534):434-5.

89. Rahmanian F, Simbar M, Ramezankhani A, Zayeri F. Gender sensitive STIs/HIV/AIDS prevention policies: A qualitative study. Health. 2014;2014.

90. The United Nations Children's Fund (UNICEF). Looking Ahead: HIV Prevention amongst Young People in the Islamic Republic of Iran. Based on lessons learned from the Adolescent-Friendly Services Pilot Experience. 2014; Available from: http://www.unicef.org/iran/afs\%20looking\%20forwa rd.pdf.

91. United Nations Program on HIV and AIDS (UNAIDS). Islamic Republic of Iran AIDS Progress Report On Monitoring of the United Nations General Assembly Special Session on HIV and AIDS. Iran. 2015; Available from: http://www.unaids.org/sites/ 
default/files/country/documents/IRN_narrative_repor t_2015.pdf.

92. United Nations Program on HIV and AIDS (UNAIDS). HIV and AIDS estimates, Iran. 2014; Available from: http://www.unaids.org/ en/ regionscountries/ countries/ islamicrepublicofiran/.

93. United Nations Program on HIV and AIDS (UNAIDS). Islamic Republic of Iran AIDS Progress Report On Monitoring of the United Nations General Assembly Special Session on HIV and AIDS. Iran. 2014; Available from: http://www.unaids.org/ sites/default/files/en/dataanalysis/knowyourresponse/ countryprogressreports/2014countries/IRN_narrative _report_2014_en.pdf.

94. The Global Fund for Fight AIDS, Tuberculosis and Malaria. Standard concept note. Investing for impact against HIV, tuberculosis or malaria. 2014; Available from: http://www.theglobalfund.org/ documents/core/strategies/Core_GlobalFund_Strateg y_en/.

95. Shoghli A, Mohrez M. The HIV/AIDS BioBehavioral Surveilance Survey of Street children in Tehran. Centers for Disease Control and Prevention (CDC): Ministry of health and medical education, Tehran, Iran. 2010.

96. Nasirian M, Karamouzian M, Kamali K, Nabipour AR, Maghsoodi A, Nikaeen R, et al. Care Seeking
Patterns of STIs-Associated Symptoms in Iran: Findings of a Population-Based Survey. International journal of health policy and management. 2015.

97. The Joint United Nations Programme on HIV and AIDS. HIV and AIDS estimates. 2013; Available from: http://www.unaids.org/en/ regionscountries/ countries/ islamicrepublicofiran.

98. Tehrani FR, H. M-A. Knowledge, attitudes and practices concerning HIV/AIDS among Iranian atrisk sub-populations. East Mediterr Health J. 2008;14(1):142-56.

99. Lotfi R, Tehrani FR, Yaghmaei F, Hajizadeh E. Barriers to condom use among women at risk of HIV/AIDS: a qualitative study from Iran. BMC women's health. 2012;12(1):13.

100.United Nations Program on HIV and AIDS (UNAIDS). The Joint United Nations Programme on HIV and AIDS. Global report, UNAIDS report on the global AIDS epidemic. 2013; Available from: http://www.unaids.org/sites/default/files/media_asset /UNAIDS_Global_Report_2013_en_1.pdf.

Cite this article as: Janghorban R, Azarkish F. An overview on sexually transmitted infections in Iran. Int J Reprod Contracept Obstet Gynecol 2016;5:58595. 